\title{
Administrarea precoce a eritropoietinei la prematurii cu greutate foarte mică la naştere
}

\author{
Mihaela Demetrian' ${ }^{1}$ Andreea Avramescuํ, Roxana Iliescu' ${ }^{1}$ Andra Pîrnuță ${ }^{1}$, \\ Alecsandra-Ana Irimie ${ }^{2}$, Vlad Dima ${ }^{1}$ \\ ${ }^{1}$ Spitalul Clinic de Obstetrică şi Ginecologie „Filantropia“, Bucureşti, România \\ ${ }^{2}$ Facultatea de Sociologie şi Asistenţă Socială, Universitatea Bucureşti, România
}

\begin{abstract}
REZUMAT
Obiective. Studiul actual încearcă să răspundă la întrebarea dacă eritropoietina poate fi administrată „precoce“ (înainte ca prematurul să ajungă la opt zile de vârstă postnatală), în scopul de a preveni sau a reduce nevoia de transfuzii. Obiectivele secundare sunt observarea eficienţei şi siguranţei administrării precoce a eritropoietinei în reducerea comorbidităţilor specifice acestei vârste de gestaţie.

Material şi metodă. Studiu clinic randomizat, prospectiv ce a inclus 109 prematuri cu vârsta de gestaţie $\leq 30$ săptămâni şi greutate $\leq 1.250$ grame născuţi în intervalul ianuarie 2018-iunie 2019. Intervenţia terapeutică a constat în administrarea „precoce“ a eritropoietinei în primele 7 zile de viaţă, concomitent cu un preparat oral de fier. În funcţie de administrarea de eritropoietină (EPO) prematurii din studiu au fost împărţiţi în grupul EPO (n - 40) şi un grup de control $(n-69)$ care nu a primit decât preparatul oral de fier.

Rezultate. Se observă o scădere mai abruptă a hemoglobinei şi hematocritului la grupul de control începând cu săptămâna a 4-a ( 28 zile) până la 7 săptămâni, valorile ajungând să fie sensibil egale la externare. În ceea ce priveşte media numărului de transfuzii, aceasta a fost de 1,1 $\pm 0,7$ la grupul EPO versus $1,5 \pm 1,2$ la grupul de control, $p$ $=0,25$. Au existat diferenţe semnificative statistic între mediana volumului de sânge transfuzat între cele două gru-

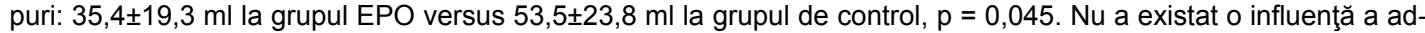
ministrării EPO asupra apariţiei hemoragiilor cerebrale $\left(X^{2}=0,86, p=0,38\right)$, asupra mucoasei intestinale $\left(X^{2}=2,89\right.$, $p=1,23)$ sau a ţesutului pulmonar $\left(X^{2}=0,7, p=1\right)$. Administrarea EPO nu a influenţat incidenţa retinopatiei de prematuritate $\left(X^{2}=0,42, p=0,59\right)$.

Concluzii. În studiul nostru, iniţierea precoce a eritropoietinei (EPO) la vârstă mai mică de opt zile a redus necesitatea transfuziilor cu 0,5 transfuzii/pacient. Volumul total (ml/ kg/pacient) de sânge transfuzat a fost redus cu $18 \mathrm{ml}$. Nu am putut dovedi efectele noneritropoietice ale EPO.
\end{abstract}

Cuvinte cheie: anemie de prematuritate, transfuzii, eritropoietină

\section{INTRODUCERE ŞI MOTIVAȚIE A STUDIULUI}

Transfuziile de concentrat eritrocitar (CE) continuă să producă cele mai multe subiecte de dispută în rândul neonatologilor. Controversele sunt legate de oportunitatea sau momentul transfuziei, cantitatea de sânge transfuzat, aplicarea unor ghiduri liberale sau restrictive, efectele pe termen scurt sau lung. Cu toate acestea, $80 \%$ dintre prematurii cu greutate foarte mică la naştere vor primi cel puţin o transfuzie de sânge până la sfârşitul spitalizării, din cauza recoltărilor frecvente de sânge sau anemiei de prematuritate. Cele mai multe transfuzii au loc în primele trei până la patru săptămâni de viaţă. Prematurii mari şi stabili răspund cel mai bine la EPO şi vor primi câteva transfuzii. Prematurii ELBW, care sunt bolnavi şi au cea mai mare nevoie de transfuzii la scurt timp după naştere, nu răspund în mod consistent la EPO. Acest lucru sugerează că EPO este un stimulator eritropoietic mult mai puternic cu cât prematurii sunt mai maturi. Prematurii ELBW sunt mult mai susceptibili de a avea nevoie de transfuzii, chiar dacă eritropoieza lor este stimulată de EPO (1). În plus, prematurii cu greutate extrem de mică la naştere au un volum sanguin mai mic şi flebotomiile repetate în scop diagnostic de-a lungul spitalizării adesea necesită transfuzii ,precoce“ în contrast cu transfuziile ,tardive“, care sunt mult mai caracteristice anemiei de prematuritate (2). Nivelurile scăzute de eritropoietină (EPO) serică la prematuri oferă o motivaţie pentru utilizarea EPO pentru a preveni sau a trata anemia. Pentru o mai bună documentare, am accesat Cochrane Database of Systema- 
tic Reviews, cheia de căutare fiind administrarea precoce de eritropoietină la prematurii cu greutate foarte mică la naştere. Există mai multe metaanalize ale studiilor ce au avut acest subiect, ultima fiind realizată în anul 2017 (3). În această metaanaliză a studiilor, au fost analizate şi efectele nonhematologice ale terapiei cu eritropoietină. Concluziile acestei metanalize au fost: administrarea precoce a EPO reduce numărul de transfuzii, volumul de sânge transfuzat şi expunerea la donatori multipli. Totuşi, diferenţele între cei trataţi şi cei din grupurile de control au fost minime şi cu o importanţă clinică limitată. Ratele de mortalitate şi morbiditate, inclusiv hemoragia intraventriculară şi enterocolita necrozantă, nu au fost modificate semnificativ prin tratament precoce cu EPO.

\section{OBIECTIVE}

Studiul actual încearcă să răspundă la întrebarea dacă eritropoietina poate fi administrată ,precoce“ (înainte ca prematurul să ajungă la 8 zile de vârstă postnatală), în scopul de a preveni sau a reduce nevoia de transfuzii de concentrat eritrocitar. Spre deosebire de administrarea tardivă de eritropoietină, beneficiul global al EPO ar putea fi mai bine relevat deoarece s-ar reduce riscul ca aceşti prematuri să fi fost expuşi la transfuzii înainte de intrarea în studiu. Obiectivele secundare sunt observarea eficienţei şi siguranţei administrării precoce a eritropoietinei în reducerea leziunilor neurologice şi a intoleranţei digestive/enterocolitei ulceronecrotice la prematurii cu greutate foarte mică la naştere; de asemenea, am urmărit dacă administrarea precoce poate influenţa comorbidităţile specifice acestei vârste de gestaţie: retinopatia de prematuritate (ROP), displazia bronhopulmonară (DBP).

\section{MATERIAL ŞI METODĂ}

Studiul s-a derulat pe o perioadă de 18 luni ( ianuarie 2018 - iunie 2019) şi a inclus 109 prematuri cu vârsta de gestaţie $\leq 30$ săptămâni şi greutate $\leq 1.250$ grame. În funcţie de administrarea de eritropoietină (EPO), prematurii din studiu au fost împărţiţi în grupul EPO şi un grup de control, care nu a primit decât preparatul oral de fier.

Criteriile de includere: vârsta de gestaţie $\leq 30$ de săptămâni şi greutate $\leq 1.250$ grame. Criterii de excludere: malformaţii congenitale/sindroame genetice, infecţii congenitale/TORCH, asfixie perinatală formă severă (scor Apgar sub 3 la 5 minute), hemoragie intraventriculară $>$ gr. 3 , boală hemolitică prin izoimunizare în sistem $\mathrm{Rh}$.

La toţi prematurii, au fost folosite strategii pentru minimalizarea pierderilor de sânge şi reducerea expu- nerii la donatori multipli: întârzierea pensării cordonului ombilical peste 60 de secunde (1-2 minute), reducerea cantităţii de sânge recoltat şi a numărului de analize care nu sunt strict necesare, aderenţă la protocolul de transfuzii. Intervenţia terapeutică a constat în administrarea ,precoce“ a eritropoietinei în primele 7 zile de viaţă. Preparatul administrat: Binocrit (Epoetin alfa), în doză de $400 \mathrm{UI} / \mathrm{kg}$, de trei ori/săptămână (luni, miercuri, vineri). Modul de administrare: subcutanat. Durata terapiei cu eritropoietină a fost de şase săptămâni, fiecare copil primind în medie 18 administrări. Terapia cu fier a fost iniţiată când alimentaţia enterală a ajuns la aproximativ $75 \%$ din nevoile nutritive sau la aproximativ $60 \mathrm{ml} / \mathrm{kg} / \mathrm{zi}$. Doza de fier: 6 $\mathrm{mg} / \mathrm{kg} / \mathrm{zi}$, dar a fost crescută până la $8-10 \mathrm{mg} / \mathrm{kg} / \mathrm{zi}$ dacă sideremia a scăzut sub $60 \mathrm{mg} / \mathrm{dl}$. Monitorizarea a constat în urmărirea săptămânală a parametrilor hematologici: hemogramă, indici eritrocitari, sideremie. S-au înregistrat: volumele de sânge recoltate pentru fiecare prematur inclus în studiu, numărul de transfuzii administrate, volumul de sânge transfuzat, vârsta postnatală la care s-a administrat prima transfuzie, valoarea hemoglobinei şi hematocritului pentru prima transfuzie efectuată. De asemenea, am urmărit eventualele efecte noneritropoietice (nonhematologice) ale terapiei EPO. Efectul trofic protector asupra mucoasei intestinale a fost evaluat prin: debutul alimentaţiei enterale, durata alimentaţiei parenterale, total calorii/proteine din alimentaţia enterală la 14 zile postnatal, aspect clinic de EUN > gr. II (clasificare Bell). Efectul neuroprotector a fost evaluat prin: leziuni cerebrale tip HIV sau ale substanţei albe tip leucomalacie periventriculară $(4,5)$. De asemenea, prematurii din studiu au fost incluşi în screening-ul pentru retinopatia de prematuritate (ROP) $(6,7)$. Studiul a fost aprobat de Consiliul de Etică al spitalului (aviz nr. 2/2018), iar pentru administrarea de eritropoietină şi/ sau concentrat eritrocitar, au existat consimţăminte informate semnate de aparţinătorii pacienţilor. Toate datele au fost introduse în programul Epi Info 7 şi au fost prelucrate în segmentul Analysis.

\section{REZULTATE}

$\mathrm{Au}$ intrat în studiu 116 de prematuri, dintre care, pentru culegerea şi prelucrarea datelor, au rămas la final un număr de 109. Dintre aceştia, 40 au primit terapie cu eritropoietină în primele 7 zile de viaţă, iar 69 de prematuri au primit doar terapie orală cu fier. Vârsta de gestaţie a prematurilor din studiu s-a situat între 23 şi 30 de săptămâni $(27,4 \pm 1,8$ grupul EPO vs. $28,6 \pm 1,9$ - grup control), iar greutatea la naştere între 550 şi 1.300 grame (medie $969 \pm 186$ grame grupul EPO vs $1.096 \pm 275$ grame - grup control). 
Datele comparative între cele două grupuri sunt prezentate în tabelul 1. Se observă că prematurii din grupul EPO au avut toţi nevoie de ventilaţie mecanică şi au făcut forme mai severe de detresă respiratorie. 33 de prematuri din grupul EPO (75\%) au necesitat administrare de surfactant, iar în grupul de control 30 $(42 \%), p=0,001$. Se remarcă administrarea minimum invazivă (LISA/INSURE) la grupul de control (65\% vs. $18 \%$ ). În grupul EPO, modurile invazive de ventilaţie au fost mai frecvente şi durata de ventilaţie faţă de grupul de control a fost mai mare: medie 13,1 vs 9,5 zile $(\mathrm{p}=0,21)$. În grupul EPO, au existat forme mai severe de detresă respiratorie, instabilitatea hemodinamică a fost mai frecventă, necesitând mai mult suport inotrop decât în grupul de control $67,5 \%$ versul $27,5 \%, p=0,0034$. Deşi durata oxigenoterapiei la grupul EPO a fost mai mare faţă de grupul de control (medie de 36,3 vs. 26,9 zile), incidenţa bronhodisplaziei nu a diferit semnificativ între cele două grupuri: $12,5 \%$ (EPO) vs. $14,3 \%, p=0,77 . \mathrm{Nu}$ au fost diferenţe semnificative din punct de vedere nutriţional: iniţierea alimentaţiei a fost în general în primele două zile de viaţă (1,6 vs. 1,8 zile), cu o durată medie a alimentaţiei parenterale de 10 zile, cu un aport caloric similar
(135 calorii $/ \mathrm{kg}$ ), dar cu un spor ponderal mai mare la grupul de control (114 vs. 93 grame) la 14 zile de viaţă, $\mathrm{p}=0,05$.

\section{Curbele de hemoglobină şi hematocrit}

Se observă o scădere mai abruptă a hemoglobinei şi hematocritului la grupul de control începând cu săptămâna a 4-a ( 28 zile) până la 7 săptămâni, valorile ajungând să fie sensibil egale la externare. Aceeaşi evoluţie şi în cazul hematocritului (8). Un splitplot ANOVA a arătat că diferenţa dintre Hb1 şi Hb10 a scăzut semnificativ statistic la grupul control faţă de grupul EPO $(\mathrm{F}=6,92, \mathrm{p}=0,01)$. Un test split plot ANOVA a arătat că diferenţa dintre scăderea Htc-ului între momentul 10 (externare) şi momentul 1 (naştere) a fost semnificativ mai mare la grupul control comparativ cu scăderea la grupul EPO $(\mathrm{F}=9,64, \mathrm{p}=$ 0,00) (vezi Fig. 1, Fig. 2, Fig.3, Fig. 4). Se observă cum curbele volumului eritrocitar parcurg acelaşi traseu: eritrocite cu volum mare la naştere (115-117 pg), care scad pe măsură ce vârsta postnatală creşte. $\mathrm{Nu}$ sunt diferenţe de evoluţie a VEM între cele două grupuri şi ele corespund cu datele din literatură (8).

TABELUL 1. Caracteristici demografice şi clinice ale celor două grupuri \#

\begin{tabular}{|l|c|c|c|}
\hline Variabile & EPO grup (n-40) & Control grup (n-69) & P value \\
\hline Vârsta gestațională (spt.) & $27 \pm 1,8(23-30)$ & $28 \pm 1,9(24-30)$ & 0,08 \\
\hline Greutatea la naştere (g) & $969 \pm 43(650-1.300)$ & $1.096 \pm 27(550-1.250)$ & 0.05 \\
\hline Profilaxie cu steroizi & $65 \%(26)$ & $59 \%(41)$ & 0,58 \\
\hline Operație cezariană (\%; $n)$ & $76 \%(30 / 40)$ & $60 \%(40 / 71)$ & 0,08 \\
\hline Preeclampsie (\%; $n)$ & $13 \%(5)$ & $39 \%(13)$ & 0,11 \\
\hline Corioamnionită & $12 \%(4)$ & $10 \%(7)$ & 0,4 \\
\hline Scor Apgar la 5 minute & $6,6 \pm 1,3$ & $6,4 \pm 1$ & 0,44 \\
\hline Ventilație mecanică & $84,3 \%(59)$ & $100 \%(40)$ & 0,07 \\
\hline Mod de ventilație noninvaziv (SNIPPV*) & $55,9 \%(33)$ & $25 \%(10)$ & 0,01 \\
\hline Surfactant & $30(75 \%)$ & $30(42 \%)$ & 0,001 \\
\hline LISA/INSURE** & $18 \%(5)$ & $65 \%(19)$ & 0,01 \\
\hline Durata ventilației mecanice(zile) & $13,1 \pm 1,3(2-39)$ & $9,5 \pm 1,7(2-70)$ & 0,21 \\
\hline Durata oxigenoterapiei (zile) & $36,3 \pm 4,8(1-94)$ & $26,9 \pm 4,3(1-117)$ & 0,06 \\
\hline Medicație inotropă & $67,5 \%(27)$ & $27,5 \%(19)$ & 0,0034 \\
\hline Persistență de canal arterial tratată cu Pedea & $15 \%(6)$ & $20 \%(14)$ & 0,65 \\
\hline Displazie bronhopulmonară & $14,3 \%(10)$ & $12,5 \%(5)$ & 0,77 \\
\hline Debutul alimentației enterale (zile) & $1,6 \pm 1$ & $1,8 \pm 1,7$ & 0,54 \\
\hline Durata alimentației parenterale (zile) & $10,7 \pm 5,6$ & $9,1 \pm 5,2$ & 0,09 \\
\hline Calorii la 14 zile/kg & $136,3 \pm 26$ & $134 \pm 21$ & 0,70 \\
\hline Aport proteic la 14 zile (grame/kg/zi) & $3,3 \pm 0,4$ & $3,3 \pm 0,5$ & 0,86 \\
\hline Plus ponderal la 14 zile (grame) & $93 \pm 34$ & $114 \pm 88$ & 0,05 \\
\hline Sepsis precoce & $28 \%(11)$ & $55 \%(37)$ & 0,02 \\
\hline Sepsis tardiv & $18 \%(7)$ & $10,4 \%(7)$ & 0,75 \\
\hline Durata spitalizării & $67,7 \pm 17$ & $63,9 \pm 24$ & 0,40 \\
\hline
\end{tabular}

*SNIPPV - synchronous nasal intermitent positive pressure ventilation, **LISA - low invasive surfactant administration, INSURE - intubation-surfactant-extubation; \# valori: mediana \pm DS, minim-maxim, procent/număr absolut 


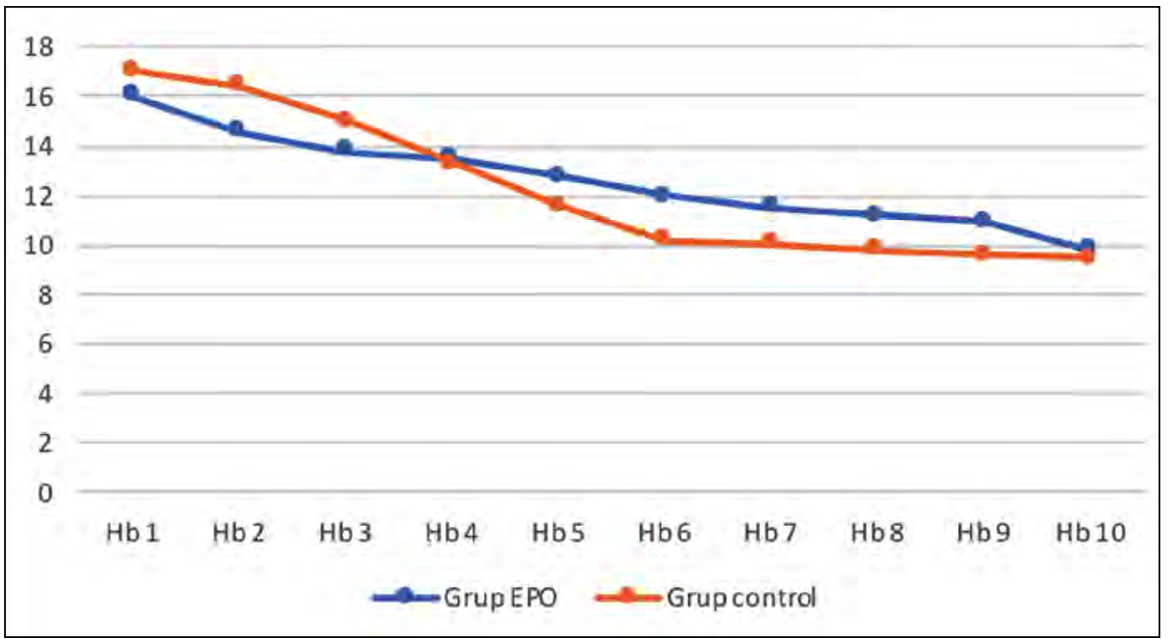

FIGURA 1. Curbele de hemoglobină la cele două grupuri

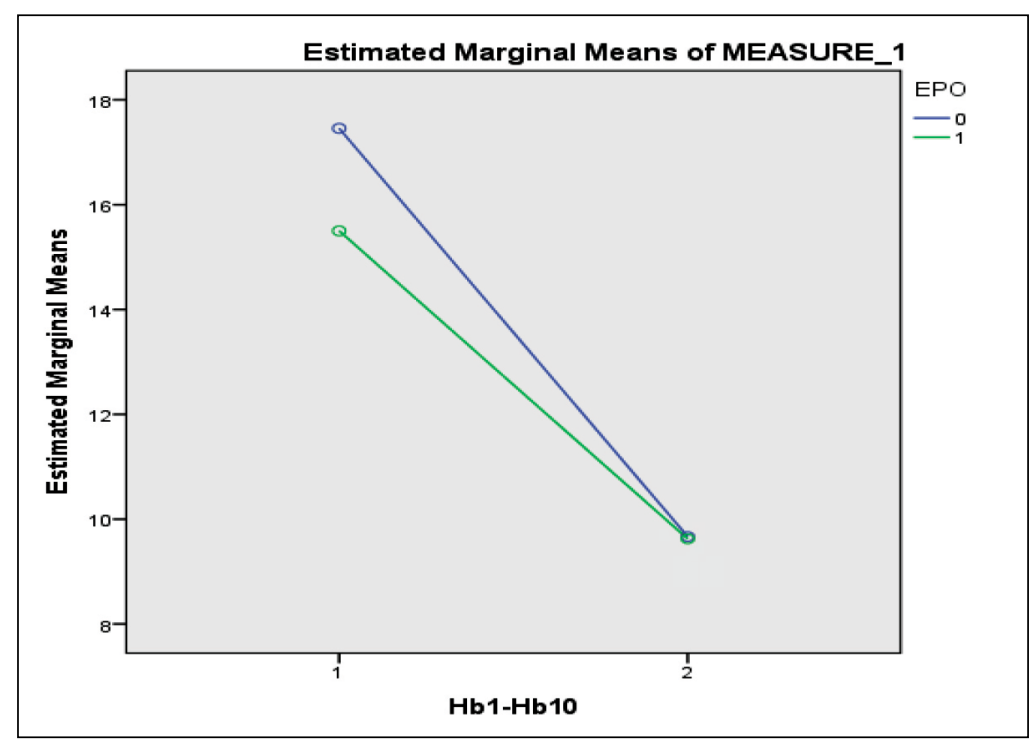

FIGURA 2. Split-plot Anova - Variațiile hemoglobinei la cele două grupuri

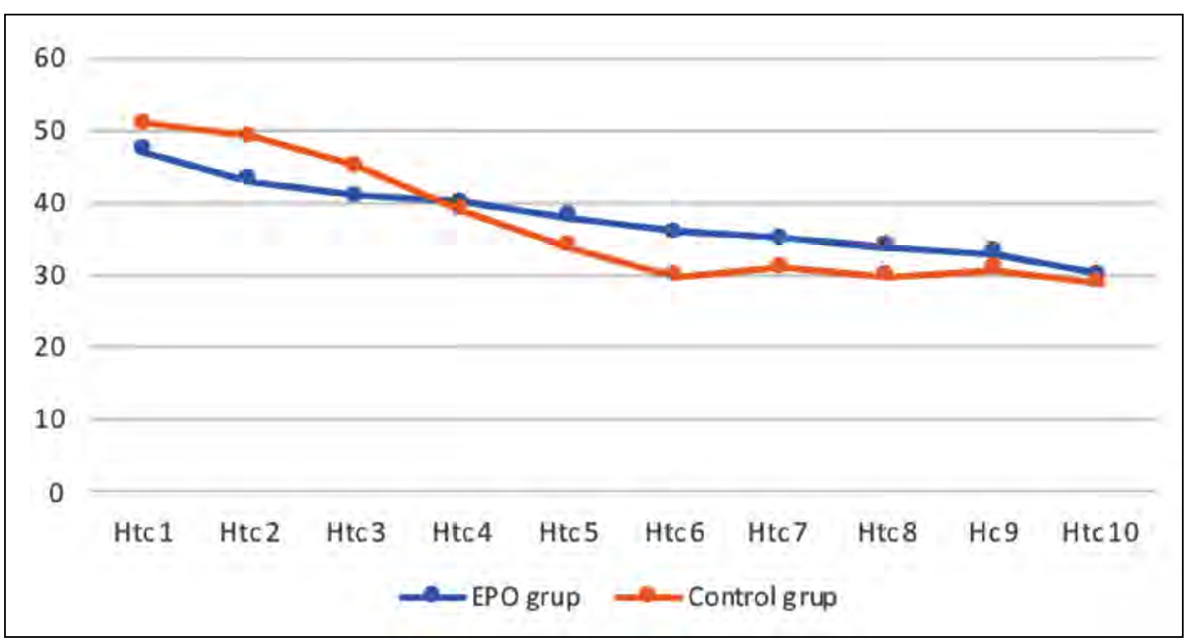

FIGURA 3. Curbele hematocritului la cele două grupuri 


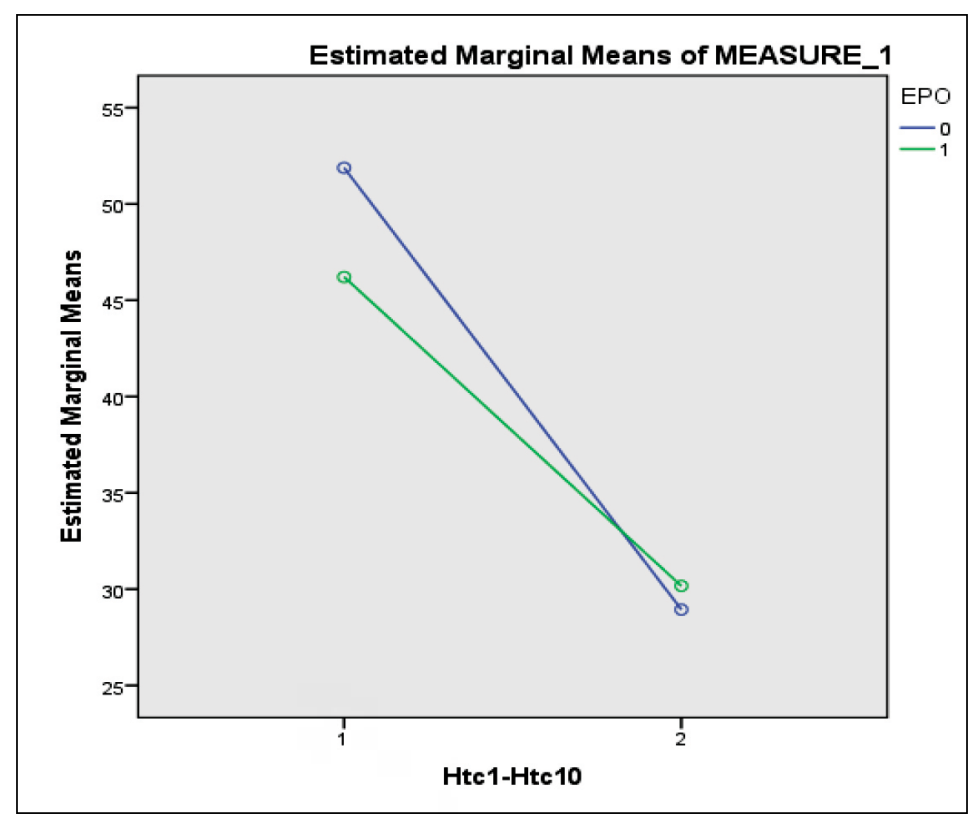

FIGURA 4. Split-plot Anova - Variațiile hematocritului între cele două grupuri

\section{Transfuziile de concentrat eritrocitar (CE)}

În timpul internării, au existat 51 de transfuzii la cele două grupuri: 13 la grupul EPO şi 38 la grupul de control. Vârsta postnatală la care s-a administrat prima transfuzie a fost aproximativ 35 zile, cu o variaţie de 1-88 zile, şi nu a diferit semnificativ la cele două grupuri $(29,3 \pm 23,5 \mathrm{EPO}$ versus $37,1 \pm 19,7$ zile grupul de control), $\mathrm{p}=0,25$.

Deoarece s-a aplicat acelaşi protocol de transfuzie, valorile hemoglobinei şi hematocritului nu au avut diferenţe semnificative între cele două grupuri: $8,2 \pm 2$ versus $7,7 \pm 1,5 \mathrm{~g} / \mathrm{dl}, \mathrm{p}=0,18$ şi 27,3 versus $23,5 \pm 4,8 \%$, $\mathrm{p}=0,73$. În ceea ce priveşte media numărului de transfuzii, aceasta a fost de $1,1 \pm 0,7$ la grupul EPO (1-3) versus 1,5 $\pm 1,2$ (1-6) la grupul de control, $\mathrm{p}=$ 0.25 . Un test Mann-Whitney U a arătat că nu a existat o diferenţă semnificativă statistic între mediana numărului de transfuzii pentru subiecţii din grupul EPO $(\mathrm{Md}=1, \mathrm{n}=13)$ şi cea a subiecţilor din grupul control $(\mathrm{Md}=1,5, \mathrm{n}=38)$. Au existat diferenţe semnificative statistic între mediana volumului de sânge transfuzat între cele două grupuri. $35,4 \pm 19,3 \mathrm{ml}$ la grupul EPO versus $53,5 \pm 23,8 \mathrm{ml}$ la grupul de control, $\mathrm{p}=0,045$. Aplicând Mann-Whitney U test, am demonstrat o diferenţă semnificativă statistic între mediana volumului transfuziilor la grupul Epo $(\mathrm{Md}=33, \mathrm{n}=13)$ şi cea a grupului control $(\mathrm{Md}=46,5, \mathrm{n}=38)$. Deoarece factorii asociaţi cu nevoia de transfuzie se pot suprapune cu cei care contribuie la comorbidităţile specifice prematurilor ELBW, am folosit analiza regresiei lineare pentru a delimita influenţa unor factori de risc ca vârsta de gestaţie, nevoia de suport inotrop, durata ventilaţiei mecanice, prezenţa sepsisului precoce/tardiv, cantitatea de sânge recoltat. Am găsit că există o core- laţie negativă între VG $(p=0,019)$, durata ventilaţiei mecanice $(p=0,03)$ şi nevoia de transfuzie. Este totuşi de remarcat că, deşi prematurii din grupul EPO au avut forme mai severe de boală pulmonară şi mai multă nevoie de ventilaţie mecanică, numărul de transfuzii şi media volumului transfuzat au fost, totuşi, mai mici. Aceasta şi datorită faptului că prelevările sanguine pentru analiza gazelor sanguine au fost minime şi foarte judicioase. Asta se reflectă în media volumului de sânge recoltat/pacient, care nu a diferit semnificativ între cele două grupuri $(22,4 \pm 7,5$ grup EPO vs. 19,2 $\pm 5,7$, grup de control, $p=0,1)$.Cele mai multe transfuzii au fost administrate după 28 de zile la ambele grupuri.

\section{Efectele noneritropoietice ale EPO}

Unul dintre scopurile propuse ale studiului a fost acela de a observa efectele eritropoietinei în scăderea incidenţei hemoragiilor cerebrale, cunoscându-se efectul neuroprotector al acesteia. $\mathrm{Nu}$ au existat diferenţe semnificative ale incidenţei hemoragiilor intraventriculare (> gr. 3)/leucomalaciei periventriculare (LPV) între cele două grupuri. Un test exact al lui Fisher a arătat că nu a existat o influenţă a administrării EPO asupra apariţiei hemoragiilor cerebrale $\left(\mathrm{X}^{2}=\right.$ $0,86, p=0,38)$. De asemenea, nu a putut fi dovedit efectul protector asupra mucoasei intestinale: 2 copii din grupul EPO (5\%) şi 11 din grupul de control (16\%) au prezentat semne de EUN, dar numai stadii 1 şi 2. Testul exact Fisher a arătat că nu a existat o influenţă a eritropoietinei asupra mucoasei intestinale, $\left(\mathrm{X}^{2}\right.$ $=2,89, \mathrm{p}=1,23$ ) la fel şi asupra ţesutului pulmonar $\left(\mathrm{X}^{2}=0,7, \mathrm{p}=1\right)$ sau a incidenţei retinopatiei de prematuritate $\left(\mathrm{X}^{2}=0,42, \mathrm{p}=0,59\right)$. 
TABELUL 2. Incidența comorbiditătilor specifice prematurilor ELBW la cele două grupuri

\begin{tabular}{|l|c|c|c|c|}
\hline Variabile & $\begin{array}{c}\text { Grup } \\
\text { EPO }\end{array}$ & $\begin{array}{c}\text { Control } \\
\text { grup }\end{array}$ & $\begin{array}{c}\text { Test exact } \\
\text { Fisher }\end{array}$ & P value \\
\hline $\begin{array}{l}\text { Incidența leziunilor } \\
\text { cerebrale } \\
\text { (HIV > gr. 3, LPV) }\end{array}$ & $\begin{array}{c}3,5 \% \\
(3 \text { cazuri })\end{array}$ & $\begin{array}{c}5,5 \% \\
(6 \text { cazuri })\end{array}$ & $X^{2}=0,86$ & 0,38 \\
\hline $\begin{array}{l}\text { Incidența } \\
\text { ROP > gr. 3 }\end{array}$ & $\begin{array}{c}5,2 \% \\
(2 \text { cazuri })\end{array}$ & $\begin{array}{c}1,64 \% \\
(1 \text { caz })\end{array}$ & $X^{2}=0,42$ & 0,59 \\
\hline $\begin{array}{l}\text { Incidența EUN } \\
\text { std. 1-2 }\end{array}$ & $\begin{array}{c}5,1 \% \\
(2 \text { cazuri })\end{array}$ & $\begin{array}{c}15,9 \% \\
(11 \text { cazuri })\end{array}$ & $X^{2}=2,89$ & 1,23 \\
\hline Incidența DBP & $\begin{array}{c}12,5 \% \\
(5 \text { cazuri })\end{array}$ & $\begin{array}{c}14,3 \% \\
(10 \text { cazuri })\end{array}$ & $X^{2}=0,7$ & 1 \\
\hline
\end{tabular}

Incidenţa ROP $>$ gr. 3 şi a enterocolitei ulceronecrotice (EUN) în studiul nostru nu a putut fi corelată cu numărul de transfuzii $(\mathrm{p}=0,88)$, cantitatea de sânge transfuzat $(\mathrm{p}=0,71)$ şi vârsta postnatală $(\mathrm{p}=0,88)$ la care s-au administrat transfuziile (9).

\section{DISCUȚII}

În studiul nostru, iniţierea precoce a eritropoietinei (EPO) la vârstă mai mică de 8 zile a redus necesitatea transfuziilor cu 0,5 transfuzii/pacient. Volumul total $(\mathrm{ml} / \mathrm{kg} /$ pacient) de sânge transfuzat a fost redus, la fel ca numărul donatorilor printre toţi subiecţii randomizaţi - dar nu la prematurii transfuzaţi. Aceasta corespunde cu datele din metaanaliza studiilor privind administrarea precoce a eritropoietinei (3), în care s-a evidenţiat faptul că EPO reduce semnificativ transfuziile cu una sau mai multe /pacient, volumul de sânge transfuzat și numărul de expuneri la donatori multipli. Pentru toate aceste rezultate, effect size a fost mic şi susceptibil de a avea o importanţă clinică limitată. Deşi cele două grupuri studiate au fost uniforme din punct de vedere demografic, patologia respiratorie la grupul EPO a fost mult mai severă şi era de aşteptat ca nevoile transfuzionale să fie mai mari în acest grup (10). Este posibil ca această diferenţă în patologia respiratorie să fi influenţat rezultatul terapiei cu EPO. În general, la această categorie de prematuri, transfuziile de CE asigură un anumit nivel al hemoglobinei care depinde de nivelul de suport cardiorespirator necesar. Aproape jumătate dintre transfuziile de CE sunt administrate în primele două săptămâni la prematurii cu greutate extrem de mică la naştere, când boala cardiorespiratorie este mai severă şi prelevările de laborator sunt maxime; în prima săptămână, pierderile prin flebotomie pot ajunge la $10-30 \%$ din volumul sanguin $(10-25 \mathrm{ml} / \mathrm{kg})(11)$. In studiul nostru, nu am putut dovedi efectul eritropoietinei în neuroprotecţie; numărul prematurilor cu leziuni cerebrale (HIV>gr. 3) a fost foarte redus în cele două grupuri şi e greu de făcut o corelaţie statistică semnificativă. În ultima revizuire a metaanalizelor pe studiile EPO, incidenţa hemoragiei intraventriculare (HIV grad III şi IV) şi cea a leucomalaciei periventriculare a scăzut semnificativ. În privinţa retinopatiei de prematuritate în studiul nostru nu a fost observate forme agresive, deşi au existat studii care demonstrau o creştere nesemnificativă a ratei de retinopatie de prematuritate (>stadiul 3) în cazul administrării precoce de eritropoietină (6). În schimb, transfuzia de concentrat eritrocitar în primele 10 zile de viaţă a fost asociată cu creşterea de 4 ori a riscului de retinopatie severă independent de vârsta de gestaţie sau de displazia bronhopulmonară (9-11). Efectele protectoare ale eritropoietinei asupra mucoasei intestinale $\mathrm{nu}$ au putut fi dovedite în studiul nostru. $\mathrm{Au}$ existat doar forme uşoare de EUN (std. 1 şi 2) în ambele grupuri şi a fost greu de făcut o corelaţie cu efectul protector al eritropoietinei versus transfuzii de CE. Alterarea oxigenării sau perturbarea perfuziei mezenterice în timpul transfuziei au fost implicate în fenomenul denumit ,leziune acută a intestinului în raport cu transfuzia“" (TRAG - transfusion related acute injury of gut) (12-16). Deşi rezultatele acestor metaanalize referitoare la impactul transfuzional nu pot recomanda deocamdată eritropoietina în tratamentul standard al anemiei de prematuritate, efectele noneritropoietice ale acesteia (în special cele de neuroprotecţie) constituie o promisiune şi o provocare pentru continuarea studiilor (17).

\section{CONCLUZII}

În studiul nostru, iniţierea precoce a eritropoietinei (EPO) la vârstă mai mică de 8 zile a redus necesitatea transfuziilor cu 0,5 transfuzii/pacient. Volumul total (ml/kg/pacient) de sânge transfuzat a fost redus cu 18 ml. Administrarea precoce a eritropoietinei (EPO) poate reduce numărul de transfuzii cu una sau mai multe transfuzii/pacient, volumul de concentrat eritrocitar transfuzat scade, de asemenea şi numărul de donatori/pacient. Deşi semnificative din punct de vedere statistic, aceste reduceri au o importanţă clinică limitată.

În studiul nostru, ca şi în actualizările curente ale metaanalizelor pentru administrarea precoce a EPO, cu dovezi de înaltă calitate conform GRADE, nu se observă o creştere semnificativă a ratei de retinopatie (ROP) (stadiul $\geq 3$ ). Deşi rezultatele din metaanalizele recente au arătat o calitate moderată a dovezilor conform cărora EPO reduce hemoragia intraventriculară (HIV), leucomalacia periventriculară (LPV) şi EUN, rezultatele din studiul nostru nu au dovedit acest lucru. 


\section{BIBLIOGRAFIE}

1. Kotto-Kome AC, Garcia MG, Calhoun DA, Christensen RD. Effect of beginning recombinant erythropoietin treatment within the first week of life, among very-low-birth-weight neonates, on "early" and "late" erythrocyte transfusions a meta-analysis. Journal of Perinatology 2004; 24(1): 24-9.

2. Garcia MG, Hutson AD, Christensen RD. Effect of recombinant erythropoietin on "late" transfusion in the neonatal intensive care unit: A meta-analysis. Journal of Perinatology 2002;22(2);108-11.

3. Ohlsson A, Aher SM. Early erythropoietin for preventing red blood cell transfusion in preterm and/or low birth weight infants. Cochrane Database of Systematic Reviews 2014, Up-Date 2017, Issue 4. Art. No.: CD004863.

4. Juul S. Neuroprotective role of erythropoietin in neonates. Journal of Maternal-Fetal \& Neonatal Medicine 2012; 25 (Suppl 4):105-7.

5. Jakab A., Ruegger C., Bucher HU, Makki M, Huppi PS,Hagmann C, Swis EPO Neuroprotection Trial Group Network based statistics reveals trophic and neuroprotective effect of early high dose erythropoetin on brain connectivity in very preterm infants. Neuroimag. Clin 2019; 22: 101806 Epub 2019 Apr 1.

6. Ohlsson, Aher SM, Early erythropoietin for preventing red blood cell transfusion in preterm and/or low birth weight infants. Cochrane Database Syst Rev. 2012 Sep 12 ;(9): CD004863.

7. Fierson WM. American Academy of Pediatrics Section on O, American Academy of $\mathrm{O}$, American Association for Pediatric $\mathrm{O}$, Strabismus, American Association of Certified O. Screening examination of premature infants for retinopathy of prematurity. Pediatrics. 2013; 131:189-95.

8. Robert D. Christensen, MD, Erick Henry, MPH, Jeff Jopling, BS, and Susan E. Wiedmeier, MD The CBC: Reference Ranges for Neonates, Seminars in Perinatology, 2009 Elsevier.

9. Lust C, Vesouli Z, Jackups R, Liao S, Rao R, Malthur AM, Early red cell transfusion is associated with development of severe retinopathy of prematurity. J Perinatol. 2019, Mar, 39(3):393-400.
10. Howarth C, Banerjee I, Aladangady N, Red blood cell transfusions in preterm infants: current evidence and controversies. Neonatology 2018; 114:7-16.

11. Wang Y, Chan O, Chiang M, Yang P. Red Blood Cell Transfusion and Clinical Outcomes in Extremely Low Birth Weight Preterm Infants. Pediatr Neonatol. 2017; 58(3):216. Epub 2016 Jul 5.

12. Dani C, Poggi C, Gozzini E, Leonardi V, Sereni A, Abbate R, Gori AM: Red blood cell transfusions can induce proinflammatory cytokines in preterm infants. Transfusion 2017; 57: 1304-1310.

13. Song J, Sun H, Xu F, Kang W. Recombinant human erythropoietin improves neurological outcomes in very preterm infants. Ann Neurol. 2016 Jul;80(1):24-34.

14. J. Blau, JM Calo, D Dozor, M Sutton, G Alpan, EF La Gamma. Transfusion-related acute gut injury: Necrotizing enterocolitis in very low birth weight neonates after packed red blood cell transfusion. J Pediatr, 158 (2011), pp. 403-409.

15. MB Wallenstein, YH Arain, KL Birnie, J Andrews, JP Palma, WE Benitz et al. Red blood cell transfusion is not associated with necrotizing enterocolitis: A review of consecutive transfusions in a tertiary neonatal intensive care unit. J Pediatr, 165 (2014), pp. 678-682.

16. Patel RM, Knezevic A, Shenvi N, Hinkes M, Keene S, Roback JD, Easley KA, Josephson CD. Association of red blood cell transfusion, anemia, and necrotizing enterocolitis in very low-birth-weight infants. JAMA 2016; 315: 889-897.

17. Aher SM, Ohlsson A. Late erythropoiesis-stimulating agents to prevent red blood cell transfusion in preterm or low birth weight infants. Cochrane Database Syst Rev. 2019;2. 